\title{
COOPERATIVE GRACE, COOPERATIVE AGENCY
}

\author{
KEVIN TIMPE \\ Northwest Nazarene University
}

\begin{abstract}
In an earlier paper, I argued for an account of the metaphysics of grace which was libertarian in nature but also non-Pelagian. My goal in the present paper is to broaden my focus on how the human and divine wills relate in graced activities. While there is widespread agreement in Christian theology that the two do interact in an important way, what's less clear is how the wills of two agents can be united in one of them performing a particular action via a kind of joint or unitive willing. Insofar as the goal in these unitive willings is to have the human will and the divine will operating together in the human bringing about a particular action, I refer to this kind of volition as 'cooperative agency. I explore two different models - an identificationist model and an incarnation model - regarding how the human agent is aligned with God in cooperative agency. I then argue that there are significant reasons for preferring the incarnational model over the identificationist model.
\end{abstract}

\section{INTRODUCTION}

In an earlier paper, I argued for an account of the metaphysics of grace according to which the following two claims are true:

Claim 1: divine grace is the efficient cause of saving faith, and

Claim 2: humans control whether or not they come to saving faith. ${ }^{1}$

\footnotetext{
${ }^{1}$ There are, of course, different kinds of grace and what follows will not be relevant to all of them. My focus on grace should be restricted to just those cases involving human action and excluding, among other things, the grace of creation.
} 
The motivation for Claim 1 was to avoid running afoul of the antiPelagian constraint (APC), a constraint I think Christian philosophers and theologians have good reason to try to satisfy:

(APC): No fallen human individual is able to cause or will any good, including the will of her coming to saving faith, apart from a unique grace. $^{2}$

The motivation for Claim 2 was to be able to preserve the compatibility of that account with a libertarian account of free will, thereby avoiding commitment to theological determinism in the affirmation of Claim 1.

In that paper, I focused on just those acts of will involved in coming to saving faith. I confess that I've always been somewhat uncomfortable with that earlier view given the metaphysical cost it required - namely the truth of certain controversial (but, I still think, plausible) claims about causation (e.g., that omissions can't be causes but instead are merely quasi-causes). If there's another account that can preserve both Claim 1 and Claim 2, I'd welcome it; ${ }^{3}$ I suspect that what I say in the present paper could be joined with such an account as well. But assuming for now the model that I developed earlier, my goal is to broaden my focus on how the human and divine wills relate in graced activities. ${ }^{4}$ Rather than focusing simply on how the two relate to the act of coming to saving faith, I here want to think about the relationship between the human will and the divine will more broadly. ${ }^{5}$ While there is widespread agreement in Christian theology that the two do interact in an important way, what's less clear is how the wills of two agents can be united in one of them performing a particular action via a kind of joint or unitive willing.

\footnotetext{
${ }^{2}$ For my defence of (APC), see Timpe (2007).

${ }^{3}$ For other accounts of how the human will relates to grace, see Stump (2001) and Ragland (2006). See Timpe (2007) for why I reject these accounts.

${ }^{4}$ The relationship here will be something other than mere concurrence, even though this is a minimal condition for the exercise of created agents' powers: 'However great created functional powers may be, they can do nothing without Divine concurrence .... In general concurrence, genuine Divine agency does not compete with genuine created agency .... God creates, sustains, and concurs with any created agent whatever.' (Adams 2013: 23f.)

${ }^{5}$ For instance, the Catechism of the Catholic Church gives the following example: 'God inspired the human authors of the sacred books. "To compose the sacred books, God chose certain men who, all the while he employed them in this task, made full use of their own faculties and powers so that, though he acted in them and by them, it was as true authors that they consigned to writing whatever he wanted written, and no more'" (144)
} 
Insofar as the goal in these unitive willings is to have the human will and the divine will operating together in the human bringing about a particular action, I will refer to this kind of volition as 'cooperative agency'. While there may be many other examples of cooperative agency broadly speaking (e.g., a husband and wife willing in tandem regarding the raising of their children), my focus here will only address cooperative agency regarding humans and God. In addition to satisfying both Claim 1 and Claim 2 above, I think any satisfactory account of cooperative agency needs to capture a tight connection between the human agent's will and God's desire for what the human agent should do. Furthermore, I think that the agent should identify with God's desire in her willing. That is, there should not just be a parallel between the divine and the human wills, but a genuine alignment (which will be described below in terms of identification). It is in virtue of this that a true union will be at the heart of cooperative agency.

In what follows I'll look at two different models - an identificationist model and an incarnation model - regarding how the human agent is aligned with God in graced willings. It is also important to keep in mind that both models are just that - models, rather than fully spelled out positions. Each could itself be developed in a number of more specific ways. But at the level of detail that I'll be able to specify these models here, I think there are significant reasons for preferring the incarnational model over the identificationist model.

\section{IDENTIFICATIONIST MODELS}

The first model of cooperative agency is built on identificationist accounts of free will, such as that found in the work of Harry Frankfurt. In this section, I first outline Frankfurt's identificationist view of free will. I then show how one could model an account of cooperative agency on that view. I then argue that while the identificationist account of cooperative agency has a number of important positive features, it ultimately fails.

Harry Frankfurt advances an influential hierarchical account of freedom of the will. ${ }^{6}$ (Frankfurt's view is often also called a 'structuralist' or 'mesh' account of the will, since, as detailed below, a will is free if it has a certain internal structure or 'mesh' among the various levels of

\footnotetext{
${ }^{6}$ See Frankfurt (1988), particularly chapter 2.
} 
desires and volitions.) For Frankfurt, free will (or what Frankfurt calls 'freedom of the will') isn't simply about a person forming a volition on the basis of a desire. Free and responsible agency is not 'a simple act that merely implements a first-order desire. It essentially involves reflexivity, including desires and volitions of a higher order' (Frankfurt 1988: 176). According to Frankfurt, 'the enjoyment of a free will means the satisfaction of certain desires - desires of the second or higher orders' (Frankfurt 1988: 22). Second-order desires are 'desires concerning what first-order desire they want to be their will' (Frankfurt 1988: 164). ${ }^{7}$ For Frankfurt, just as freedom of action is being able to do what one wants to do, freedom of the will is being able to have the kind of will that one wants to have. If a second-order desire moves the agent to act on the first-order desire that is the object of that second-order desire, then she has a second-order volition. In such a case, Frankfurt writes,

$A$ wants the desire to $X$ to be the desire that moves him effectively to act. It is not merely that he wants the desire to $X$ to be among his desires by which, to one degree or another, he is moved or inclined to act. He wants this desire to be effective - that is, to provide the motive in what he actually does. (Frankfurt 1988: 15)

On this view, for example, Allison freely decides to take her dog for a walk in the park if she desires to go for a walk with her dog, and she desires that the previously mentioned desire be the reason why she actually goes for a walk; that is, she identifies with that desire. ${ }^{8}$ If, on the contrary, the desires that lead individuals to act are desires with which the agents do not identify, then we are 'moved to act by something other than what we really want' and 'moved by a force that is not fully our own' (Frankfurt 1988: 164).

Frankfurt's hierarchical view has been subject to much (and I think compelling) criticism. ${ }^{9}$ For present purposes, the most important is the

${ }^{7}$ As indicated above, Frankfurt also thinks there can be higher-order desires as well.

${ }^{8}$ For how Frankfurt understands identification, see, for instance, Stefaan Cuypers: 'Frankfurt further describes the formation of second-order volitions in terms of identification. A person who desires that a certain desire constitutes his will, identifies himself with it; conversely, he withdraws himself from it when he does not desire to be motivated by such a desire. There is an important sense in which a desire with which a person identifies himself is more truly his own, whereas a desire from which he withdraws himself is not really his own, although it may still remain part of his ongoing stream of consciousness' (Cuypers 1998: 46).

${ }^{9}$ For some of them, see Timpe (2012a), particularly chapter 8 . 
idea that desires of a higher order are themselves insufficient to account for free will. Susan Wolf, for instance, writes that 'no matter how many levels of self we posit, there will still, in any individual case, be a last level - a deepest self about whom the question "What governs it?" will arise, as problematic as ever' (Wolf 1987: 52). And a similar criticism has been raised by Gary Watson. ${ }^{10}$ Responding to this line of criticism, in 'Identification and Wholeheartedness' Frankfurt writes that

Someone does what he really wants to do only when he acts in accordance with a pertinent higher-order volition. But this condition could not be sufficient unless the higher-order volition were itself one by which the person really wanted to be determined. Now it is pretty clear that this requirement cannot be satisfied simply by introducing another desire or volition at the next higher level. [...] The mere fact that one desire occupies a higher level than another in the hierarchy seems plainly insufficient to endow it with greater authority or with any constitutive legitimacy. (Frankfurt 1988: 166)

But if identification is to help avoid the worry that Wolf and Watson raise, it must involve more than just higher levels of desire. It is for this purpose that Frankfurt introduces the concept of being 'wholehearted'. The idea of being wholehearted about a particular desire aims to illustrate that the person is not divided about that desire; that is, there are no higher-level conflicts about it. ${ }^{11}$ Robert Kane nicely captures Frankfurt's view here as follows:

Persons are 'wholehearted' when there are no conflicts in their wills [at the various levels of desires] and they are not ambivalent about what they want to do. Ambivalent persons, by contrast, are of two (or more) minds about what they want to do and cannot make up their minds. Reflection on our desires stops, says Frankfurt, when we reach desires to which we are wholeheartedly committed and to which we have no ambivalence. It is not arbitrary, he insists, to identify with such wholehearted desires because they are the desires with which we

10 'Since second-order desires are themselves simply desires, to add them to the context of a conflict is just to increase the number of contenders; it is not to give a special place to any of those in contention.' (Watson 1975: 218)

${ }^{11}$ Frankfurt thinks there is another kind of division within an agent's volitional structure - one that involves a conflict between 'how someone wants to be motivated and the desire by which he is in fact most powerfully moved' (1988: 165) - but this kind of division need not concern us at present. 
are 'fully satisfied' and we have no 'active interest' in bringing about a change in them. (Kane 2005: 96f.)

Wholeheartedness, for Frankfurt, does not require the complete absence of conflicts among an agent's desires. Rather, Frankfurt understands that an agent can be wholehearted even if his desires conflict so long as he decisively identifies with one of these desires and separates himself from the other. Instead, wholeheartedness involves a person endorsing a particular desire in the belief that no further accurate inquiry would require him to change his mind' (Frankfurt 1988: 169). The agent is 'committed' to that desire. As a result of this commitment, 'terminating the sequence at that point - the point at which there is no conflict or doubt - is not arbitrary'. (Frankfurt 1988: 169) ${ }^{12}$ Thus, in answer to Wolf's question 'What governs the hierarchy?', Frankfurt holds that the agent in question does in virtue of endorsing wholeheartedly a particular level of desire past which there is no more conflict in the agent's volitional structure and past which she thinks no further reflection is necessary.

More could be said about Frankfurt's view of freedom of the will, but the above should be sufficient for developing the first model of cooperative agency I want to explore. Drawing on his account, an identificationist model of cooperative agency can be understood along the following lines. An agent $A$ wills cooperatively with God regarding some action $x$ only if $A$ 's second-order desire is for God's firstorder desire regarding $x$. That is, even if $A$ can't bring herself to have the first-order desire to $x$, she wants God's desire for her to $x$ to move her to action. Merely having such a second-order desire will be insufficient, of course, for cooperative willing for the same reasons that merely having a second-order desire is insufficient for free will. Building then on Frankfurt's developed view, we might add that cooperative agency requires not just the second-order desire for God's desire to become the agent's will, but also that the agent wholeheartedly identify with that desire. To put it schematically, we can say:

Identificationist Cooperative Agency:

Agent $A$ and God are engaged in cooperative agency regarding some action $x$ if and only if:

${ }^{12}$ Here, Frankfurt notes the etymological root of 'to decide' as 'to cut off': 'This is apt, since it is characteristically by a decision [...] that a sequence of desires or preferences of increasingly higher orders is terminated. When the decision is made without reservation, the commitment it entails is decisive.' (Frankfurt 1988: 170) 
(i) God desires $A$ to do $x$;

(ii) $A$ has a second-order desire, $D$, for God's desire for her to do $x$ to become her volition;

(iii) $A$ identifies with $D$;

(iv) $A$ is wholehearted regarding $D$; and

(v) $A$ subsequently forms a volition to $x$ as a result of her wholehearted identification with $D$.

Using Frankfurt's terminology, we can also say that because of (v), the second-order desire in (ii) becomes the agent's second-order volition. And, in light of (iii) and (iv), this is a second-order volition with which the agent wholeheartedly identifies. Let me give an example here to illustrate. First, suppose that Emmaline has \$20. She desires to spend it on something for herself that, while she would enjoy it, she does not need. She also knows that God desires His people to engage in acts of charity, say by giving the money to Oxfam. She wants her volition to be in line with God's desire, even if she also has a conflicting first-order desire to spend the money on herself. She has no further higher-order desires which conflict with her second-order desire for God's desire to become her will. That is, she wholeheartedly identifies with God's desire to give her money to charity. As a result of her identifying wholeheartedly with God's desire in this way, she forms the volition to give the money to Oxfam, cooperatively acting with God to bring about an act of charity.

I think this model gets a number of things correct regarding cooperative agency. For one, I think it's right that the agent identifies in an important sense with God's desire for her. ${ }^{13}$ Second, I think that identification needs to play an explanatory role in why the agent does the action in question; this explanatory role is captured by (v) in the above schema. Furthermore, in virtue of this explanatory role, the individual is united with God's will in an important way - the agent is making God's desire be her will. ${ }^{14}$

Despite thinking that the identificationist model is right in these regards, I think that ultimately it fails as an analysis of cooperative agency when we look at an example of the volition involved in coming to faith.

\footnotetext{
${ }^{13}$ See Stump (forthcoming) for an excellent account of how an agent's identifying and aligning herself with God will lead to psychic integration.

${ }^{14}$ This point is inspired by a comment by Alex Pruss: 'When one participates in a popular devotion because it is popular, one is thereby united in will with the community in which the devotion was popular.'
} 
In particular, I think the conditions outlined above are neither necessary nor sufficient to explain an agent's act of coming to saving faith.

To see why these conditions are not sufficient, consider the case for Magdalen's conversion, that is, going from status corruptionis to status gratiae. ${ }^{15}$ Creatures in the status corruptionis suffer from a 'spiritual illness of the post-Fall human condition. ${ }^{16}$ While being in this state affects many - perhaps even all - aspects of human nature, the foundational defect is in the will. One hallmark of this defect is the will's internal fragmentation, its intractability to itself, its proneness to moral wrong even against its own desires for the good. ${ }^{17}$ According to Christian theology, given this defect in the will an agent is not able to be the efficient cause of her moving from the status corruptionis to status gratiae. This is why, in his writings against Pelagius and his disciples, Augustine repeatedly emphasizes that 'cooperative grace' or what Augustine calls 'a unique grace ${ }^{18}$ is needed. ${ }^{19}$ Similarly, Aquinas writes that 'a man cannot perform meritorious deeds without grace. ${ }^{20}$ And the Council of Trent declares that 'the efficient cause [of our justification is] the God of mercy who, of his own free will, washes and sanctifies, placing his seal and anointing with the promised holy Spirit who is the guarantee of our inheritance. ${ }^{21}$ These sorts of considerations are what motivates (APC). So Magdalen is not able to form the first-order volition to come to saving faith on her own. The identificationist model aims at getting around this by making the effective first-order desire God's desire, with which the agent identifies with at a higher order. ${ }^{22}$ But here

${ }^{15}$ For more on the role these two states play in philosophical anthropology, see Timpe (2014), chapter 1 and Timpe \& Jenson (2015).

16 Stump (forthcoming), p. 1 in draft.

${ }_{17}$ Stump (forthcoming), p. 1 in draft.

${ }^{18}$ See for example Augustine's On Nature and Grace in (1992), Saint Augustine: Four Anti-Pelagian Writings, 69.

${ }^{19}$ For why I think Pelagius' view is often misunderstood on this point, see Timpe (2007).

20 Aquinas, Truth, 24.1 ad 2 in Schmidt, ed. (1954: 139).

${ }^{21}$ Council of Trent, Sixth Session, Chapter VII, as quoted in Tanner (1990: 673). Also note that efficient causation is the only kind of causation that I am concerned with in the present paper.

${ }^{22}$ Maximus the Confessor writes that, in the Garden of Gethsemane, the human will is subjected to the divine will: 'Earlier reflection on the Agony in the Garden had interpreted this in terms of the human submission of the Incarnate Will to the divine will: in making explicit that this must involve the submission of a human will to the divine will Maximus was breaking new ground' (Louthe 1996: 58). I want to suggest 
the identificationist model of cooperative agency faces a dilemma. Either the agent is the efficient cause of her coming to faith, or she's not. On either horn, the initial constraints of a satisfactory account of cooperative agency are violated.

Consider first that the agent is the efficient cause of her second-order volition to make God's desire her will. In such a case, (APC) is violated, not at the level of first-order volitions, but instead at the second-order of volition. ${ }^{23}$ For willing that God's desire becomes one's will is itself to will the good, since one's alignment with God's desires is a good thing. And according to (APC), no human in the status corruptionis is able to cause or will any good apart from a unique grace.

Consider then the second horn of the dilemma. On this horn, it is not the agent herself that is the cause of her second-order volition for coming to saving faith. Given that we're talking about cooperative agency between human agents and God, the natural alternative explanation is that God is the efficient cause of the volition in question. Were Frankfurt himself a theist, I think that this is the horn of the dilemma hed prefer - that is, that God can cause the agent to have the required second-order volition to come to saving faith. Frankfurt candidly admits that he only cares about the internal relationships within an agent's volitional structure, not how her volitional structure got to be the way it is; so presumably he'd say that the relevant volition could be caused directly by God:

The only thing that really counts is what condition I am in. How I got into that condition is another matter. If I'm in the condition where I'm doing what I want to do and I really want to do it, i.e., I decisively identify with my action, then I think I'm responsible for it. It makes no difference how it came about that that is the case. [...] If the person is wholehearted in the action, let us say performs the action because he wants to perform it and the desire to perform it is a desire that he really wants to have and there's no reservation, there's no imposition, no passivity: the person is completely, fully, wholeheartedly identified with what's going on. What more could there be? What more could you want? That's all the freedom that's possible for human beings to have, in my opinion. [...]

that something similar happens in cooperative agency, and I think that this can best be accounted for by the incarnational model below.

${ }^{23}$ See also Stump (forthcoming), footnote 1. It wouldn't resolve the problem here to push the issue up to the third-order level or higher, for reasons related to Wolf's criticism of Frankfurt's view above. 
What accounts for the fact that he's completely wholehearted is no longer relevant. The only important consideration is that he is doing exactly what he wants to do and he's totally satisfied with doing this. (Frankfurt 1988: 32ff. $)^{24}$

And in another article, Frankfurt writes that 'the degree to which his choice is autonomous and the degree to which he acts freely do not depend on the origin of the conditions which lead him to choose and to act as he does' (Frankfurt 1988: 46).

This might be an option for the compatibilist, though not all compatibilists find such a view plausible. Al Mele, for instance, finds this aspect of Frankfurt's view 'difficult to accept' (Mele 2008: 270) ${ }^{25}$ despite being sympathetic with much of the rest of it, insofar as Mele thinks that such direct manipulation would undermine free will. But it's especially hard to see how an incompatibilist could accept this horn of the dilemma. For starters, incompatibilists think there are problems with Frankfurt's hierarchical analysis of freedom of the will. ${ }^{26}$ As an account of cooperative agency and not free will in general, this view also conflicts with Claim 2, which is itself motivated by incompatibilist concerns: humans control whether or not they come to saving faith.

So no matter which horn of the dilemma one takes, I think we have good reason for rejecting the identificationist model of cooperative agency as sufficient for cooperative agency. But I also think we have reason to think that it isn't necessary either. Criterion (iv) requires the agent to be wholehearted regarding her second-order desire for God's desire for her salvation to become her will. And while I don't want to rule out that religious conversations can be wholehearted in this way, and I think that ultimate perfect union with God would be wholehearted in this way, I don't see why coming to saving faith would require it. Remember from above that as Frankfurt understands wholeheartedness, it can involve conflict among an agent's desires so long as the agent identifies decisively with one of them and separates herself from the other. In this context Frankfurt writes that

\footnotetext{
${ }^{24}$ In 'Identification and Wholeheartedness', Frankfurt also criticizes Aristotle's account of responsibility given its 'preoccupation with causal origins and causal responsibility' (1988: 171).

${ }^{25}$ See also McKenna (2011) for a worthwhile discussion of Frankfurt's view on this point.

${ }^{26}$ See footnote 9 above.
} 
When someone identifies himself with one rather than another of his own desires, the result is not necessarily to eliminate the conflict between those desires, or even to reduce is severity, but to alter its nature. [...] The conflict between the desires is in this way transformed into a conflict between one of them and the person who has identified with its rival. That person is no longer uncertain which side he is on, in the conflict between the two desires, and the persistence of this conflict need not subvert or diminish the wholeheartedness of his commitment to the desire with which he identifies. (Frankfurt 1988: 172)

But surely those who are united to God in faith can be conflicted not just between a desire and the self but rather within the self. Thus, by extension, it seems that people could also be conflicted in the act of coming to faith. Paul, for instance, writes that he does not do the good that he wants, but instead the evil that he does not want (Romans 7:19). Surely there is a sense in which Paul wants (and thus sees as good) the evil in question; so I think we should interpret Paul as making a secondorder claim here. And so it seems that Paul is indeed 'uncertain which side he is on.' ${ }^{27}$

While I'm less certain about this claim that the identificationist criteria are not necessary for cooperative agency, even if they merely aren't sufficient, I think the identificationist model should be rejected as an account of the very nature of cooperative agency.

\section{INCARNATIONAL MODEL}

The other model, and the one that I think is ultimately more promising, understands cooperative agency between humans and God along the lines of how the divine and human wills relate to each other in the Incarnation. For this reason, I shall refer to it as the incarnational model. Before I can get to the model, however, I have to address the norms governing one's reflection on the Incarnation. Following Scott MacDonald, my methodology in approaching such topics is what he calls 'clarification'. The philosophical theologian engaged in clarification

can legitimately undertake the investigation of not only the question of God's existence and attributes - issues associated with traditional

${ }^{27}$ I think a similar claim could be made regarding Augustine in the Confessions shortly after his conversion. 
natural theology - but also doctrines such as trinity, incarnation, and atonement - traditional paradigms of doctrines inaccessible to natural reason. When the philosopher takes up these kinds of issues with the aim of articulating and developing them, probing their internal coherence, joint consistency, and systematic connections, and exploring their relations to other theological and nontheological doctrines, she will be engaged in appropriately philosophical reflection on specifically Christian theological matters. (MacDonald 2009: 23)

In light of this methodology, I have certain constraints that I take to govern what is acceptable to say regarding the Incarnation, even if I do not defend the normativity of those constraints here. I'm going to take as my primary guiding constraint the Christology found in the earliest seven Ecumenical Councils - the Councils held as binding by both Catholic and Orthodox Christians. ${ }^{28}$ More specifically, what I have in mind is what Oliver Crisp calls 'dogmatic minimalism'. Speaking of the Chalcedonian definition, which he takes to be a good example of this sort of theological approach that he's advocating, Crisp writes that it is minimalistic because the definition says as little as doctrinally possible about the hypostatic union, while making clear that certain ways of thinking about the person of Christ are off-limits, or unorthodox' (Crisp 2013: 27). ${ }^{29}$

${ }^{28}$ As Sturch (1991) argues, the primary purpose of the early councils was not to establish a single orthodox position, but to rule out positions that are not orthodox (1991: 214). Similarly, Crisp (2013) writes that if we bear in mind that the dogmatic hardcore of classical Christology is rather thin, and deliberately so, it should help us to see that there may be many different Christologies that are consistent with the canons of Chalcedon' (2013: 28).

${ }^{29}$ Relatedly, Crisp writes: 'God would not permit the church to come to a substantially mistaken account of the person of Christ and to encode this in a canonical decision in an ecumenical doctrine, for what we think about the person of Christ touches the heart of Christian doctrine, and therefore the heart of the gospel. It is an impoverished doctrine of providence that claims otherwise.' (2013: 24)

Crisp's dogmatic minimalism is a weaker claim than Tim Pawl's 'Conciliar Christology', which refers to the conjunction of the teachings from the earliest seven Ecumenical Councils. 'The conjuncts of this conjunction come from definitions and expositions of faith, creeds, canons, and anathemas of the councils. If such conciliar statements include other documents [...] then I will include the Christological teachings from those documents as conjuncts of Conciliar Christology, too' (Pawl, in progress), chapter 1, p. 2 in draft). While I am inclined to strive to meet compatibility with Conciliar Christology, for purposes of expediency I'll restrict myself to Crisp's dogmatic minimalism. 
There are, of course, complicated questions in the vicinity regarding the exact boundaries of Christological orthodoxy. But I don't think I need to demarcate them further for my present purposes. It is clear that dogmatic minimalism includes the following from Third Constantinople, which canonized dyothelitism, the claim that Christ has two wills:

[W] proclaim equally two natural volitions or wills in him and two natural principles of action which undergo division, no change, no partition, no confusion, in accordance with the teaching of the holy fathers. And the two natural wills not in opposition, as the impious heretics said, far from it, but his human will following, and not resisting and struggling, rather in fact subject to his divine and all powerful will. For the will of the flesh had to be moved, and yet to be subjected to the divine will, according to the most wise Athanasius. For just as his flesh is said to be and is flesh of the Word of God, so too the natural will of his flesh is said to and does belong to the Word of God. [...] For in the same way that his all holy and blameless animate flesh was not destroyed in being made divine but remained in its own limit and category, so his human will as well was not destroyed by being made divine, but rather was preserved. ${ }^{30}$

And regarding the two wills in the Incarnation, Cyril of Alexandria writes (in a letter that Chalcedon would latter accept as authoritative) that in Christ 'two different natures come together to form a unity.' ${ }^{31}$

Drawing on earlier work by Garrett DeWeese, Crisp affirms an axiom that he calls the Chalcedonian Axiom (CA):

(CA) Christ has one of whatever goes with the person and two of whatever goes with natures. ${ }^{32}$

${ }^{30}$ In Tanner (1990: 128). Though not an ecumenical council, the Lateran Council in 649 asserted the following:

Canon 10: 'If anyone does not properly and truly confess according to the holy Fathers two wills of and the same Christ our God, united uninterruptedly, divine and human, and on this account that through each of His natures the same one of His own free will is the operator of our salvation, let him be condemned.' (Denzinger, The Sources of Catholic Dogma, para. 263; as quoted in Pawl (2014: 236)).

${ }^{31}$ As quoted in Pawl (in progress: chapter 1, p. 5). The Second Council of Nicea would later 'declare that there are two wills and principles of action, in accordance with what is proper to each of the natures of Christ'.

${ }^{32}$ Crisp (2013: 32); DeWeese (2007: 115). One can find an affinity, it seems to me, between what Crisp and DeWeese are advocating and the doctrine of double consubstantiality'. 
And insofar as each nature has a will, Christ must have, via (CA), two wills. ${ }^{33}$ When Chalcedon speaks of 'two principles of action' it means 'two things by which action can come, referring to the two natures. When these two principles of action align in a particular action, there are not two actions but one - one action of the one person who has two natures. We can speak, in this one person, of the divine will being united to a created will as God being united with a human agent - after all, this is how Aquinas speaks of the human soul: 'We do not call Christ a creature, speaking absolutely, since his name signifies the hypostasis. But we say that Christ's soul or body is a creature.' (Aquinas 2009: 172) While there may be two wills willing an action, there are not therefore two actions. ${ }^{34}$ So in the Incarnation we have two wills united in such a way as to produce one singular action. Jesus Christ 'goes up' to Jerusalem in virtue of both His human nature and divine nature willing His body to so walk. And this, I shall argue, provides a way of understanding how human wills and divine wills align in cooperative agency. When Emmaline gives her \$20 to Oxfam, this one act of charity is accomplished by her uniting her will with God's will in a single act.

At this point, I think it will be helpful to pause to address a worry that may arise. The worry can be understood in two ways, one of which I think can be dispatched with pretty easily. The second version of the worry will lead to the need to be explicit about two disanalogies between the Incarnation and cooperative agency more generally. My discussion of the second disanalogy will then lead to further development of the Incarnational Model.

The worry is about the attempt to use the Incarnation to elucidate and explain cooperative agency. This worry might be understood in two ways. The stronger way of understanding the worry is that reflection on the relationship between the human will and nature, on the one hand, and the divine will and nature on the other is misplaced. After all, Cyril describes the hypostatic union of the two natures as an 'ineffable union' (Tanner 1990: 41, 72) and Second Constantinople declares as anathema

${ }^{33}$ Louth (1996) refers to the doctrine of two wills in the Incarnation as 'an entailment of the doctrine of the two natures' (1996: 17). The Council of Chalcedon in 451 affirmed that the Incarnate Christ has 'two natures which undergo no confusion, no change, no division, no separation; at no point was the difference between the natures taken away through the union, but rather the property of both natures is preserved and comes together into a single person and a single subsistent being.'

${ }^{34}$ See also Stump (2003: 447ff.). 
anyone who does not 'confess a belief in our one Lord, understood in both his divinity and his humanity, so as by this to signify a difference of natures of which an ineffable union has been made' (Tanner 1990: 117). ${ }^{35}$ The worry about ineffability here can be seen as a demanding version of negative theology that eschews all positive claims about the divine nature. I don't see the strong version of the ineffability worry as a genuine worry. After all, the reflection that the early ecumenical councils engaged in not only made claims about the divine nature and hypostatic union, but this was in fact the point. ${ }^{36}$

The weaker way of understanding the worry, one that I have some sympathy with, is that even if speaking of the relationship between the two natures in the Incarnation isn't inappropriate because ineffable, we're attempting to understand something more common (namely, cooperative agency in general) via something considerably less common, indeed singular (namely, the Incarnation). As mentioned above, I have some sympathy with this way of understanding the worry. But here's why I don't think the worry undermines the present project. Christians are already committed to the interaction of the two wills in the Incarnation. Indeed, as pointed out earlier, it's a requirement of dogmatic minimalism. As I've argued elsewhere regarding free will, even if we are more familiar with human freedom than we are divine freedom, there is still reason to think that the latter is the primary sense of free will. ${ }^{37}$ And so, given commitment to dyothelitism, I don't think it inappropriate to use the relationship between the two wills as a model for understanding

35 Maximus the Confessor, whose view I reference below, also referred to the hypostatic union as 'the great mystery' (Louth 1996: 55).

${ }^{36}$ For more on this, see Pawl (forthcoming: chapter 1).

${ }^{37}$ In Timpe (2012b), I wrote the following: 'To use a common example from Christian theology, the meaning of the predicate involved in saying "God is a loving father" is not univocal with the meaning of the predicate involved in saying "Brent is a loving father". But neither are the two meanings completely equivocal, for presumably what it means for God to be a loving father bears a significant relationship to what it means for Brent to be a loving father. Saying what exactly this relationship is is at the heart of an analogical approach to religious language. Analogical predication can be approached either through the order of being or the order of knowing. So, to return to our example, what it means for Brent to be a loving father is grounded in, or dependent upon, what it means for God to be a loving father. The order of being is thus grounded in God. But epistemically, we first become aware of what it means to be a loving father through humans such as Brent and then later come to realize what it means for God to be a loving father. This is the order of knowing.' (Timpe 2012b: 89) 
cooperative agency more generally. But it is exactly at this point that the two disanalogies must be addressed.

The first disanalogy is this: the union in the Incarnation is the union of two wills (and two complete natures more fully) into one person - it is a hypostatic union. 'There is one person in Christ. So there is one subject of predication, one fundamental entity to which we refer when we speak of Christ. But this person has two complete, unconfused natures.' (Crisp 2013: 32) While our cooperation with God unites us with God in an important sense, we neither become the same person as God nor have our personhood taken up into the divine person in the sense that our personhood becomes a part of the three persons that are the Divine Nature. So far as I can tell, nothing of importance for the incarnational model of cooperative agency hangs on this disanalogy. ${ }^{38}$

The second disanalogy will require a more lengthy response. In the case of the Incarnation, the human will that was engaged in cooperative agency with the divine will was untainted by sin, original or actual. The two wills were always, as a matter of fact, aligned with each other. ${ }^{39}$ But this is not so of normal cases of cooperative agency: other human wills

38 There is a tradition in parts of Christianity that appears to endorse that we can approach such a hypostatic union. Maximus the Confessor was shaped by Evagrius, who held that 'we can attain equality with Christ, become isochristoi' (Louth 1996: 24). While I find this a fascinating suggestion and think that the Eastern Church's understanding of deification may also lead in this direction, I will not pursue this option in greater detail here. See also pages 34f., as well as Opuscules 3 and 7 reprinted therein for Maximus on deification. I think that the connections between Maximus' understanding of deification and the above treatment of cooperative agency are deserving of further attention. And compare Adams's discussion of Peter Lombard's view of the hypostatic union between the Holy Spirit and the human will in Adams (2013: 28f.).

${ }^{39} \mathrm{I}$ 'm inclined to think that it is only a contingent truth that the human will and the divine will in the Incarnation were always aligned. So far as I can tell, both this and the stronger claim that they were necessarily aligned are within the bounds of dogmatic minimalism. In personal correspondence, Tim Pawl has suggested the following middle position between the two above options: 'My view is that Christ's human nature [CHN] was not essentially morally perfect, but the person of Christ is impeccable. $\mathrm{CHN}$ is not essentially morally perfect because, on my view, it could have existed but not been assumed. In such a case, it would fulfill the conditions for being a supposit, and so also for being a person. That person, call him Walter, would not have been essentially morally perfect. He could sin. And so $\mathrm{CHN}$ is not essentially morally perfect. If that sounds scandalous, we can note that it is something in the neighborhood of essentially morally perfect. It - and any nature that is assumable - is such that, necessarily (if it is assumed, then it is unable to sin in that circumstance).' See also Stump (2003: 417f.). 
fail to be aligned with the divine will. ${ }^{40}$ And so we need an account of what happens with the wills which do not align in such a case.

The matrix for understanding the possibilities here is going to be complex: there are a number of different moral valences for what is being willed (morally good, morally bad, morally neutral); two wills; three 'settings' for a particular will (willing $x$, willing $\sim x$, being quiescent regarding $x$ ); as well as two different stages of theological anthropology that need to be incorporated: the status corruptionis and the status gratiae. I'm going to narrow down the options in ways that I think are well motivated.

The first way to narrow down the possible permutations is by eliminating all those options according to which God wills against what is morally good. Given essential moral perfection, I don't see it as an option for God to will in such a way. I'm also going to, for purposes of simplicity, eliminate those options where what is being willed is morally neutral. ${ }^{41}$ Also, given essential moral perfection, I take it that God would never be quiescent regarding a good..$^{42}$ This leaves the following options, where $x$ is an all-things-considered good option:

(A) a corrupt human will wills $x$ and God wills $x^{43}$

(B) a corrupt human will is quiescent regarding $x$ and God wills $x$

(C) a corrupt human will wills $\sim x$ and God wills $x$

(D) a graced human will wills $x$ and God wills $x^{44}$

(E) a graced human will is quiescent regarding $x$ and God wills $x$

(F) a graced human will wills $\sim x$ and God wills $x$.

(APC) rules out possibility (A), and so I will not consider it further.

First, I want to consider the two options where the human will wills in opposition to the divine will, options (C) and (F). In these cases, the

${ }^{40}$ Depending on one's theological views, Mary may be another counterexample to the claim that human wills fail to be aligned with God's will.

${ }^{41}$ Those instances that involve an agent coming to have saving faith won't be morally neutral. Whether or not one thinks that a redeemed human can engage in cooperative agency towards something that is morally neutral in other cases will depend on other aspects of one's theology.

${ }^{42}$ I mean something that is pro toto good, not just pro tanto good. See Wiland (2012) for the difference between pro toto and pro tanto.

${ }^{43}$ Here and in (B) and (C), by 'corrupt human will' I mean the will of a human who is in the status corruptionis.

${ }^{44}$ Here and in (E) and (F), by 'graced human will' I mean the will of a human who is in the status gratiae. 
human willing wins out and the agent fails to do $x$ freely. (I presume that God can determine an agent to do $x$, even if $\mathrm{He}$ cannot determine the agent to freely do $x$. But in such a case, we're talking coercion rather than cooperative agency.) So in cases involving contrary wills regarding the relevant human free action, the human will trumps the divine will. On the assumption of incompatibilism, God cannot make a human freely do $x$ by an act of His will.

Consider then option (B). This is the kind of example I had in mind in my earlier paper on grace. That view gives the correct output - if an agent is quiescent regarding $x$ and God wills $x$, then God can bring about $x-$ while it is also the case that the human agent controls (in the relevant sense of 'control' spelled out there) $x$. But in general I don't think this control is sufficient for our cooperating with God's volition in the sense at issue in the present paper. What we don't have yet, however, is an account of how the two agents are cooperative in bringing about $x$ since the human agent isn't willing it (even if she's not actively resisting it).

Here, I think some suggestions regarding joint intentions by David Velleman might be useful. In a paper on shared intentions, Velleman's goal is to given an account of 'a plural subject that isn't just a plurality of subjects. That is, it ought to involve two or more subjects who combine in such a way as to constitute one subject, just as two or more referents combine to constitute one referent when subsumed under a plural pronoun' (Velleman 1997: 30). ${ }^{45}$ And while Velleman talks about intentions rather than acts of willing, he understands them as what 'resolve[s] deliberative questions, thereby settling issues that are up to you' (Velleman 1997: 32). ${ }^{46} \mathrm{He}$ also talks about intentions as what can 'cause action', and thus a joint intention (in his sense of the term) can I think plausibly be understood as a volition. Similarly, his goal isn't to give an account of how two or more people can share the goal of producing a particular joint result (he gives the example here of two people deciding to lift a heavy sofa together), but rather it's being up

${ }^{45}$ What Velleman is trying to avoid is having 'a plural subject as a mere façon de parler, a convenient way of summarizing facts about a collection of subjects who never actually meld' (1997: 31). There are other aspects of Velleman's account that I find problematic, such as his apparent conflation of a reason and an intention (the former might be necessary for the latter, but it's not sufficient; see 39f.). But these problems need not concern us at present.

${ }^{46}$ Granted, he takes intentions to be attitudes, but this feature of his view is detachable from the rest of his account for my present purposes. 
to the two or more individuals whether or not a single joint intention or volition is formed. Velleman suggests that two agents might form a single intention to $x$ by each having an intention of the following sort: 'I will $[x]$ if you will' so long as such an intention is understood in the following way:

It means, 'I hereby frame an effective intention that's conditional on your framing an effective intention as well' - that is, 'I hereby will it, conditional on your willing likewise.' And this statement just is the conditional willing that it describes itself as being. (Velleman 1997: 45)

Now, obviously this account by itself would not serve as a complete explanation of option (B). But perhaps we can modify it as follows, incorporating an insight from the hierarchical model examined earlier. In the hope of making this clearer, I'll frame it regarding a particular agent (Magdalen) willing a particular thing $(x)$, but hopefully the way to schematize it will be relatively obvious:

In option (B), Magdalen is unable (given (APC)) to will $x$. She is, instead, quiescent regarding $x$. But suppose that her will includes the following higher-order intention: 'I will accept God's volition regarding $x$ so long as I don't will against it.' That is, if God wills me to $x$, I have the higherorder desire to let God's desire become my volition.

Now, note that this is a conditional desire, and not an actual desire (and thus not an actual volition in Frankfurt's sense). It is possible to have such a desire for a good without having, simpliciter, a good desire. In forming such a conditional desire, the agent is aligning with God's volition via the higher order desire in question (e.g., 'I will accept God's volition regarding $x$ so long as I don't will against it'). ${ }^{47}$ But there's more here than just mere alignment insofar as the agent's will plays a crucial and irreducible role (namely, that she doesn't will against God's will). Both the agent and God thus are working together to bring about a single volition in the agent, thereby genuinely cooperating. Hence, cooperative agency. And this account of (B) is explicitly constructed to avoid violating (APC). Thus, I see nothing problematic in such a view. ${ }^{48}$

${ }^{47}$ This is one reason that, despite my earlier arguments, I think that the identificationist model gets something importantly right.

${ }^{48}$ Robert Garcia, in personal correspondence, has asked if the schema would allow for the agent to be quiescent in the higher-order intention, such that the agent would accept God's volition regarding $x$ if she was merely quiescent regarding accepting God's 
Now, if this is an acceptable account of (B), it can also serve as an acceptable account of (E). The difference between the two was that on (B) the agent lacked the further grace that Augustine and Pelagius disagreed about. We don't have to worry about the uniquely graced agent violating (APC), for reasons addressed in my earlier paper. And if God can cooperate with an ungraced (in the relevant sense) agent as spelled out above regarding (B) to bring about $x$, then surely God can cooperate with a graced agent in the same way to bring about $x$.

Finally, option (D). Here too I'll begin with a conditional: if the account here can give an account of (B), then the account can also give an account of (D). Why think this conditional is true? Well, in the discussion of (E) I argued that the addition of the unique grace to the agent's will makes the account easier, not harder, since the Pelagian (and semi-Pelagian) worry is now off the table. Similarly, if an agent can engage in cooperative agency with God via her quiescence, then surely her actually willing what God wills (rather than not resisting it and being willing to endorse God's willing at a higher-level of volition) doesn't make that cooperative agency more difficult. On this option, the agent's will and the divine will are engaged in a joint volition. And I've suggested that Velleman's account of this might be $a$ (though certainly not the only) way that this might work. In willing what God wills, the agent is 'forming an effective intention to $x$ that's conditional on God's forming an intention for the agent to $x$ as well and thereby conditionally willing $x$ on God's willing $x$ likewise.' Both wills are united to bring about a single volition for the agent to $x$.

\section{CONCLUSION}

I think that such an account is not only a plausible reconstruction of what happens regarding the two wills of Christ in the Incarnation, but

volition regarding $x$. I confess that I'm not completely sure what I should say about such a case, though I'm inclined to think that mere quiescence, rather than acceptance at some level, would not be sufficiently strong to unite the agent's will with God's volition in the relevant way. On the other hand, given my thoughts about God's essential loving nature, I also think that God would give all agents the benefit of the doubt, and this gives me some reason to think that higher-level quiescence rather than acceptance might be enough. After all, I'm inclined to think that God will redeem those who, despite suffering from original sin, are not able to wilfully reject God (because of young age, impairment, or other limitation). 
also gives an account of how we humans can participate with God - in a very real sense - in bringing about His Kingdom, both in our own wills and also in the larger world. It also gives an account of cooperative agency that gets right those features that the identificationist model gets right, but provides a better way of reconciling a union between the divine and human wills in a way that preserves incompatibilism while also not violating the (APC). On this model, cooperative agency is truly a form of unitive agency, since the grace at the heart of the account aims at uniting us with God. We come to will and love what God wills and loves, not just alongside Him but united with Him. And especially for the Christian libertarian, this is a robust and cooperative sense of divine action in the world that I think we have positive reason to endorse. ${ }^{49}$

\section{BIBLIOGRAPHY}

Adams, Marilyn McCord. 2013. 'Genuine Agency, Somehow Shared? The Holy Spirit and Other Gifts', in Robert Pasnau (ed.), Oxford Studies in Medieval Philosophy, vol. 1 (Oxford: Oxford University Press), pp. 23-60

Aquinas, Thomas. 1954. Truth, trans. by Robert Schmidt, SJ (Chicago: Henry Regnery Co.)

Aquinas, Thomas. 2009. Compendium of Theology, trans. by Richard J. Regan

(Cambridge: Cambridge University Press)

Augustine. 1992. On Nature and Grace in Saint Augustine: Four Anti-Pelagian

Writings, trans. by John Mourant \& William Collinge (Washington, DC:

Catholic University Press)

Catechism of the Catholic Church, 2nd ed. (New York, NY: Doubleday, 2003)

Crisp, Oliver. 2013. 'Desiderata for Models of the Hypostatic Union', in Oliver

Crisp \& Fred Sanders (eds), Christology: Ancient and Modern (Grand Rapids:

Zondervan), pp. 19-41

Cuypers, Stefaan E. 1998. 'Harry Frankfurt on the Will, Autonomy, and

Necessity', Ethical Perspectives, 5: 44-52

${ }^{49}$ A previous version of this paper was presented at the Analytic Theology Conference on Divine Action at Innsbruck University in Austria. The participants at that conference gave me very useful suggestions on the paper which have made it better. I am especially thankful for Fr. Raphael Weichlein for encouraging me to explore the similarities between the view I advocate here and the work of Maximus the Confessor, an exploration that I found very stimulating. Robert Garcia, Aaron Cobb, Eleonore Stump, and Stephen Coles gave me useful comments on a written draft subsequent to the conference. Finally, I'm thankful for Tim Pawl, Oliver Crisp, and Jon Jacobs helping me steer clear of various theological heresies that I would not want to endorse, even if unintentionally. 
Decrees of the Ecumenical Councils, Volume II, ed. by Norman Tanner, S.J. (Washington DC: Georgetown University Press, 1990)

DeWeese, Garrett. 2007. 'One Person, Two Natures: Two Metaphysical Models of the Incarnation', in Fred Sanders \& Klaus Issler (eds), Jesus in Trinitarian Perspective (Nashville: B\&H Publishing Group), pp. 114-152

Frankfurt, Harry. 1988. The Importance of What We Care About (New York: Cambridge University Press)

Kane, Robert. 2005. A Contemporary Introduction to Free Will (New York: Oxford University Press)

Louth, Andrew. 1996. Maximus the Confessor (London: Routledge)

MacDonald, Scott. 2009. 'What is Philosophical Theology?', in Kevin Timpe (ed.), Arguing About Religion (New York: Routledge), pp. 17-29

McKenna, Michael. 2011. 'Contemporary Compatibilism: Mesh Theories and Reasons-responsive Theories', in Robert Kane (ed.), The Oxford Handbook of Free Will (New York: Oxford University Press), pp. 175-198

Mele, Alfred. 2008. 'Manipulation, Compatibilism, and Moral Responsibility', Journal of Ethics, 12: 263-286

Pawl, Timothy. 2014. 'The Freedom of Christ and The Problem of Deliberation', International Journal for Philosophy of Religion, 75 (3): 233-247

Pawl, Timothy. Forthcoming. In Defense of Conciliar Christology (Oxford: Oxford University Press)

Ragland, C. P. 'The Trouble with Quiescence: Stump on Grace and Freedom', Philosophia Christi, 8: 343-362

Stump, Eleonore. 2001 'Augustine and Free Will', in Eleonore Stump \& Norman Kretzmann (eds), The Cambridge Companion to Augustine (Cambridge: Cambridge University Press), pp. 124-147

Stump, Eleonore. 2003. Aquinas (New York, NY: Routledge)

Stump, Eleonore. Forthcoming. 'Not My Will but Thy Will Be Done: Aquinas and Eckhart on Willing what God Wills'

Sturch, Richard. 1991. The Word and the Christ: An Essay in Analytic Christology (Oxford: Oxford University Press)

Timpe, Kevin. 2007. 'Grace and Controlling what We Do Not Cause', Faith and Philosophy, 24: 284-299

Timpe, Kevin. 2012a. Free Will: Sourcehood and Its Alternatives, 2nd expanded edition (London: Bloomsbury)

Timpe, Kevin. 2012b. 'An Analogical Approach to Divine Freedom', in Susan Gottlöber (ed.), Proceedings of the Irish Philosophical Society, pp. 88-99

Timpe, Kevin. 2013. Free Will in Philosophical Theology (London: Bloomsbury) Timpe, Kevin \& Audra Jenson. 2015. 'Free Will and the Stages of Theological Anthropology', in Joshua Farris \& Charles Taliaferro (eds), Ashgate Research Companion to Theological Anthropology (Burlington: Ashgate), pp. 233-244 
Velleman, J. David. 1997. 'How to Share an Intention', Philosophy and Phenomenological Research, 57: 29-50

Watson, Gary. 1975. 'Free Agency', Journal of Philosophy, 72: 205-220

Wiland, Eric. 2012. Reasons (London: Continuum)

Wolf, Susan. 1987. 'Sanity and the Metaphysics of Responsibility', in Ferdinand Schoeman (ed.), New Essays in Moral Psychology (Cambridge: Cambridge University Press), pp. 46-62 